\title{
Effect of Mulching in Brinjal (Solanum melongena L.): A Review
}

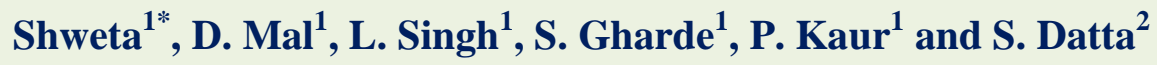 \\ ${ }^{1}$ School of Agriculture, Lovely Professional University, Punjab, India \\ ${ }^{2}$ School of Agriculture, Uttar Banga Krishi Viswavidyalaya, West Bengal, India \\ *Corresponding author
}

\section{A B S T R A C T}

Brinjal (Solanum melongena L.) can be grown best under tropical and subtropical conditions of our country. It is of great importance because its fruits have medicinal value. As it is a warm season crop, factors like high temperature, excessive soil humidity, excessive salinity, water stress adversely affect the crop growth and yield. Mulching

\section{Keywords}

Soil fertility, Yield, Brinjal, Organic mulch and Nutritional quality

Article Info

Accepted: 04 May 2018 Available Online: 10 June 2018 improved these factors essential for proper growth and increases the production. Some of the major advantages of using mulch in brinjal is weed control, earliness in yield, and also reduce disease and insect problems which affect the yield to larger extent. Both organic and inorganic mulches are improves soil properties, which directly showed the positive response on yield and yield contributing traits. Inorganic mulches like black plastic mulch is found beneficial in brinjal over organic mulches, whereas in summer brinjal organic mulch like rice straw mulch showed extremely best result with respect to soil water conservation capacity, vegetative growth and yield. On the other hand, nutrient aspects of soil also improved by using organic mulch as compared to inorganic mulch like coridia leaves provides high amount of $\mathrm{N}$ and $\mathrm{K}$ to the soil. Whereas variable concentrations micronutrients with high amount of $\mathrm{P}$ found in case of black polyethylene film. Reflective mulch showed considerable effect to repel aphid population. Ascorida leaves, rice straw mulch, black polyethylene mulch and reflective mulch found effective in Brinjal so, these mulches can be also recommended to farmers for improving the different aspects related to the yield traits for increasing the productivity and improve soil health without harming the soil macro and micro flora, fauna.

\section{Introduction}

Eggplant is an important solanaceous vegetable grown in tropical and subtropical regions of the world, but it is grown during warm season in temperate regions of the world (Rai, 1995). Purple colour of brinjal is due to pigment anthocyanin. It is of great importance because its fruits have medicinal properties, white brinjal contain highest Vitamin-A so it is effective for diabetic patients (Rajan and Markos, 2002). India grows brinjal in an area 711.3 hectare with production of $13557.8 \mathrm{MT}$ and productivity 19.1 MT per hectare (NHB, 2014-15). Crop yield will be reduced day by day due to biotic and abiotic factors. The crop is reported to be attacked by several insectpest like aphid, brinjal fruit and shoot borer (Gallo et al., 2002). Other factors that reduce yield to larger extent are: high temperature, 
excessive soil humidity, excessive salinity, water stress, weed competition. Due to weed hindrances 10 to $70 \%$ annual crop loss reported (Mani et al., 1968) and 45\% annual loss reported in sole brinjal crops (Leela 1982). So all these factors can be managed by the use of mulch (Patil et al., 2013).

There are two types of mulches that we used in agriculture. Organic mulch like straw, newspaper, dry leaves, saw dust, grass clipping, compost etc. and it can be found beneficial because these are the natural materials which requires restoration because organic mulches decay very easily. Inorganic mulching is generally used in perennial crops like Plastic mulch, synthetic mulch, polyethylene film etc. (Memon et al., 2017).

\section{Synthetic mulch}

By use of synthetic mulch like biodegradable paper, black plastic, landscape mulch; growth conditions like temperature, light intensity, relative humidity. Soil moisture can be improved. The advantageous effect of synthetic mulches was observed in microbial activity in soil, soil humidity and temperature (Perez et al., 2007) and Moreno and Moreno (2008 and 2009). As compare to organic mulches synthetic increase the soil temperature more rapidly during December and January. The plant characteristics like plant height, stem girth, fruit yield were increased efficiently by use of both organic as well as synthetic mulches. (Singh et al., 2006).

\section{Polyethylene (PE) foil, polypropylene (PP) and textile mulch}

As compared to conventional cultivation, there is significant increase in yield of brinjal when mulch with transparent foil (28.3\%), polyethylene film and polypropylene textile mulchesby $15.9 \%$ and $11.6 \%$ in case of black polypropylene textile (Sowinska et al., 2016).

\section{Plastic mulch}

Plastic mulch like HDPE, LDPE AND LLDPE is considered useful for better growing condition like weed control, temperature control, reduced salinity which reduces water loss from soil due to increased water resistance. In agricultural for more plant height, crop growth, yield farmers use different type of mulch like plastic sheet, biodegradable films etc. It is to be reported that mulching showed good influence on crop growth, crop yield and cropping species (Ashworth and Harrison, 1983). In grafted brinjal mulching with plastic mulch of thickness $25 \mu$ gives higher yield (Rajasekar et $a l ., 2017)$. Earliness, yield and quality of the vegetables crop can be improved by the use of plastic mulch (Raina et al., 1999; Bharadwaj, 2013).

\section{Black plastic mulch}

In agriculture, black plastic mulch is used commonly on large scale. In Manjari Gota variety of brinjal $15 \%$ moisture conservation whereas in Mahyco variety $20 \%$ moisture conservation was reported by the use of black polyethylene mulch (NCPAH, 1991). In some areas, due to more soil heating characters clear plastic mulch is also used on large extent. As compared to organic mulch like grass straw, cassava peel, black plastic mulch is considered more appropriate regarding weed management which gives maximum fruit yield and growth in solanaceous crops like brinjal (Asiegbu, 1991). There are many weeds grown in brinjal field which competes with main crop for food, water, sunlight, nutrition etc. were obsereved like Cynodon dactylon, Eleusine indica, Cyprus rotundus, Phyllanthus niruri, Trianthema portulacacastrum, Portulaca oleracea, Parthenium hysterophorus, Euphorbia hirta, Amaranthus virdii and Convolvulus arvensis. So all these weeds are effectively reported to be controlled by 
applying both black plastic mulch and black polyethylene mulch. Regarding yield and yield contributing characteristics black polyethylene mulch found to be best which increase the yield potential in brinjal $510.55 \mathrm{q} / \mathrm{ha}$ as compared to untreated plots (341.06q/ha) (Sumeet et al., 2017). Black plastic mulch known to increase the soil temperature from 2.2-3.4 degree Celsius as compared to unmulched soil during early crop season.

\section{Coloured mulch}

Yield of most of the vegetable crops increase by use of different colour reflective mulch by reducing disease and insect-pest population. Silver, aluminum or gray colour reflective mulch improve quality and yield parameters by attracting aphids, reduce several viral diseases like mosaic and increase the root growth, photosynthesis rate (Brown et al., 1992; Chalfant et al., 1977; Porter and Etzell, 1982; Schalk and Robbins, 1987; Stapleton and Summers, 1995).

Sprayable coloured soil mulches and silver mulches were found to improve soil properties like soil healthy, porosity, texture etc. and subsequently increasing yield in Brinjal (Stapleton et al., 1995).

\section{Colour of mulches}

Each colour of plastic mulch that use in agricultural have there on benefits:

Black- It worms the soil and control the weeds effectively.

White- It is coolest of all colour but black plastic mulch control weeds more effectively than white mulch. It is used mostly in hot climate.

Silver- It is known to reduce weeds and insect population.
Clear/Transparent- It controls soil borne diseases by solarizing the soil.

Red- It is mostly used to increase yield in vegetables (Memon et al., 2017).

\section{Organic mulch}

In organic mulching soil surface is covered with crop remains of harvested crop such as leaf stubble, maize stalk, paddy straw and husk. Mulching with crop residue is reported to be best for more yield in crop likes groundnut and cassava (Chakraborty et al., 2008 and Ghosh et al., 2006). Organic mulches improves soil properties, add organic matter to the soil and attracts many insects like cut worm, slugs etc. that's why these are used in agriculture on large scale (Memon et al., 2017).

In brinjal grown in Rabi season mulching with trash mulch and plastic mulch maximum yield were observed in coastal areas of South Gujarat. While the physical properties of the soil like hydraulic conductivity (HC), water stable aggregates (WSA); biological properties like fungi and bacterial population; chemical properties like soil fertility and soil salinity were recorded to be improved by the use of mulches like sugarcane mulch (Kaswala et al., 2012) (Table 1).

There is wide viability regarding growth and yield parameters in Brinjal while mulched with different organic and inorganic mulches. The order of variation recorded regarding growth parameters to be: rice straw $>$ black polythene> sawdust> transparent polythene> and regarding yield parameter: rice straw> transparent polythene> sawdust> black polythene>. Therefore the best mulch for brinjal growing in summer season, regarding parameters like vegetative growth, soil water conservation and yield of brinjal observed to be rice straw mulch (Hossen et al., 2017). 
Table.1 Effect of organic and inorganic mulches on soil properties

\begin{tabular}{|l|l|l|l|l|l|}
\hline Treatments & $\begin{array}{l}\text { Soil } \\
\mathbf{p H}\end{array}$ & $\begin{array}{l}\text { Organic } \\
\text { carbon }(\mathbf{\%})\end{array}$ & $\begin{array}{l}\text { Total N } \\
(\mathbf{\%})\end{array}$ & $\mathbf{P ~ m g / K g}$ & $\begin{array}{l}\mathbf{K} \\
\mathbf{m o l} / \mathbf{K g})\end{array}$ \\
\hline Control & 6.96 & 0.40 & 0.041 & 14.03 & 0.15 \\
\hline Transparent polythene & 6.66 & 0.74 & 0.075 & 18.31 & 0.12 \\
\hline Black polythene & 7.13 & 0.70 & 0.109 & 18.13 & 0.11 \\
\hline Rice straw & 6.59 & 0.70 & 0.065 & 14.58 & 0.15 \\
\hline Saw dust & 6.03 & 1.10 & 0.130 & 16.74 & 0.14
\end{tabular}

Source: Hossen et al., 2017.

\section{Straw mulch}

Highest plant height, fruit length, fruit diameter, number of leaves, number of fruit per meter square and fruit yield in brinjal were obtained by using straw mulch of 2 and $3 \mathrm{~cm} / \mathrm{m}$ square.

Regarding yield and yield contributing traits straw mulch of $2 \mathrm{~cm}$ were recorded to be best in brinjal (Pirboneh et al., 2012).

\section{FYM mulch}

FYM mulch found to improve the soil properties like hydraulic conductivity, moisture retention capacity from $7.6-28 \%$. The leaf tissue like available $\mathrm{N}, \mathrm{P}$ and $\mathrm{K}$; exchangeable $\mathrm{Ca}$ and $\mathrm{K}$ were also recorded to increase by using FYM mulch in brinjal from 39-87\%. FYM mulch also found to increase root length density, root mass density and root volume (Singh et al., 2011).

\section{Influence of mulch on nutrient concentration of soil}

$\mathrm{N}, \mathrm{P}$ and $\mathrm{K}$ concentration of Brinjal were found to be increase with mulching operation. The plants mulched with organic mulch like Cordia leaves showed maximum concentration of Nitrogen $(3.68 \%)$ and potassium $(3.65 \%)$. The plants mulched with white polyethylene sheet results in maximum leaf tissue $\mathrm{Mn}\left(77 \mathrm{mg} \mathrm{kg}^{-1}\right)$, $\mathrm{Cu}$ (17 $\left.\mathrm{mg} \mathrm{kg}^{-1}\right)$ and $\mathrm{Fe}\left(262 \mathrm{mg} \mathrm{kg}^{-1}\right)$. $\mathrm{Zn}$ concentration was also found to be increase in the plant mulch with cordia leafs (Singh et al., 2006).

\section{Effect of different colours of plastic mulches on brinjal}

The soil properties like soil temperature and moisture were recorded to be maximum while using transparent plastic mulch followed by black plastic mulch because it absorbs more solar radiation and increase the soil moisture by minimizing evaporation rate. The vegetative characters like plant height, number of leaves, stem diameter, number of flower, etc. and fruit yield are significantly affected by using both transparent and black plastic mulches (Ahmed et al., 2016).

Different colour of mulches has direct effect on the duration of fruit set in brinjal. The days to fruit set in brinjal while using clear film mulch were observed to be 26 days followed by 46 days in case of aluminium film mulch because clear film mulch heat the soil during day time leads to maturation of fruit rapidly (Hill et al., 1982).

Mulching can make effective change in increasing horticultural crop production in water scarcity regions. Plastic mulching using black polyethylene is recommended for other vegetables and has the advantages of attaining earliness in production, better fruit quality and greater total yield

\section{References}

Ahmed, M.S.M., Manal, M.H., Moula, G.E., Farag, A.A. and Aly, A.M.M. 2016. Response of Eggplant (Solanum melongena L.) to Application of some 
Organic Fertilizers under Different Colors of Plastic Mulch. Middle East Journal of Agriculture Research. 5(4): 636-646

Ashworth, S. and Harrison, H. 1983. Evaluation of mulches for use in the home garden. Hort. Science. 18: 180-182.

Asiegbu, J.E. 1991. Response of tomato and eggplant to mulching and nitrogen fertilization under tropical conditions. Scientia Horticulturae.46: 33-41.

Bharadwaj, R.L. 2013. Effect of mulching on crop production under rainfed conditionA review. Agricultural Reviews. 34: 188197.

Brown, J.E., Goff, W.D., Dangler, J.M., Hogue, W. and. West, M.S. 1992. Plastic mulch color inconsistently affects yield and earliness of tomato. Hort. Sci. 27: 11-35.

Chakraborty, D., Nagarajan, S., Aggarwal, P., Gupta, V.K., Tomar, R.K., Garg, R.N., Sahoo, R.N., Chopra, U.K. and Kalra, N. 2008. Effect of mulching on soil and plant water status, and the growth and yield of wheat (Triticum aestivum L.) in a semiarid environment. Agricultural Water Management. 95(12): 1323-1334.

Chalfant, R.B., Jaworski, C.A., Johnson, A.W. and Sumner, D.R. 1977. Reflective film mulches, millet barriers, and pesticides: effects on watermelon mosaic virus, insects, nematodes, soil borne fungi, and yield of yellow summer squash. Journal of American Society of Horticultural Science. 102: 11-20.

Gallo et al., 2002. Manual de Entomological Agricola, Piracaba FEALQ. pp. 1-920.

Ghosh, P.K. Dayal, D. Bandyopadhyay, K.K. and Mohanty, M. 2006. Evaluation of straw and polythene mulch for enhancing productivity of irrigated summer groundnut. Field Crops Research. 99(23): 76-86.

Hill, D.E. Hankin, L. and Stephens, G.R. 1982. Mulches: Their Effect on Fruit Set, Timing and Yield of Vegetables. pp: 8-9.

Hossen, M.S., Shaikh M.M. and. Ali, M.A. 2017. Effect of Different Organic and Inorganic Mulches on Soil Properties and Performance of Brinjal (Solanum melongena L.). Asian Journal of Advances in Agricultural Research 3(2): 1-7.

Kaswala A.R., Patil, R.G., Patel, K.G., Patel, A.M., Sabalpara, A.N. and Patel, R.V. 2012. Effect of Salinity, Phasic Salinity Stress and Mulching on yield of Brinjal (Solanum melongena L.) as well as soil properties. Journal of Environmental Research and Development. 6(4): 4-6.

Leela, D. 1982. A decade of weed research in horticultural crop. Pesticides. 15: 3-8.

Mani, V.S., Gautam K.C. and Chakraborty, P 1968. Losses in crop yield in India due to weed growth. PANS. 142: 141-158.

Memon, M.S., Jun, Z., Jun, G., Ullah, F., Hassan, M., Ara, S. and Changying, J. 2017. Comprehensive review for the effects of ridge furrow plastic mulching on crop yield and water use efficiency under different crops. International Agricultural Engineering Journal. 26(2):

Moreno, M.M. and Moreno, A. 2008. Effect of different biodegradable and polyethylene mulches on soil properties and production in a tomato crop. Sci. Hort. 116: 256-263.

Moreno, M.M. and Moreno, A. and Mancebo, I. 2009. Comparison of different mulch materials in a tomato (Solanum lycopersicum L.) crop. Spanish Journal of Agricultural Research. 7(2): 454-464.

National Horticulture Database, 2014-15.

NCPAH, 1991. http://www.Ncpathindia.com/ pfdc_details.php.

Patil, S.S., Kelkar, T.S and Bhalerao, S.A. 2013. Mulching: A soil and water conservation practice. Research Journal of Agriculture and Forestry Sciences. 1(3): 26-29.

Perez, J.C., Gitaitis, R. and Mandal, B. 2007. Effects of plastic mulches on root zone temperature and on the manifestation of tomato spotted wilt symptoms and yield of tomato. Sci. Hort. 114: 90-95.

Pirboneh, H., Ghasemi, M., Gohari, A. A., Bahari, B. and Bazkiyaei, Z. B. 2012. Effect of Irrigation and Straw Mulch on Yield and Yield Components of Eggplant (Solanum melongena L.). International 
Research Journal of Applied and Basic Sciences. 3(1): 46-51.

Porter, W.C. and Etzell, W.W. 1982. Effects of aluminium-painted mulch and black polyethylene mulches on bell pepper, Capsicum cinnuum L. Hort Sci.17: 942943.

Rai, M. 1995. Catalouge on Eggplant (Solanum melongena L.) germplasms part-1. National Bureau of Plant Genetic Resources, Pusa Campus, New Delhi. pp. 1-3.

Raina, J.N., Thakur, B.C. and Verma, M.L. 1999. Effect of drip irrigation and polythene mulch on yield, quality and water use efficiency of tomato (Solanum lycopersicon L.). Indian Journal of Agricultural Research. 69:430-433.

Rajan, S. and Markos, B.L. 2002. Propagation of Horticultural Crops. Horticultutre Science Series. 6: 94.

Rajasekar, M., Udhayani, V., Swaminathan N. and Balakrishnan, K. 2017. Impact of mulching and fertigation on growth and yield of grafted brinjal (Solanum melongena L.) under drip irrigation system. International Journal of Chemical Studies. 5(3): 163-166.

Schalk, J.M. and Robbins, M.L. 1987. Reflective film mulches influence plant survival, production and insect control in fall tomatoes. Hort. Sci. 22: 30-32.

Singh, I. S., Awasthi, O. P., Sharma, B. D., More, T. A. and Meena, S. R. 2011. Soil properties, root growth, water-use efficiency in brinjal (Solanum melongena) production and economics as affected by soil water conservation practices. Indian Journal of Agricultural Sciences. 81(8): 760-3.

Singh, S., Awasthi O.P. and Meena, S.R. 2006. Influence of mulch on soil hydrothermal regimes, leaf and soil nutrient concentrations, growth and fruit yield of brinjal grown under arid ecosystem. Agropedology. 16 (2): 112-116.

Sowinska, K.A., Kryiger, M. and Turczuk, J. 2016. The yield of eggplant depending on climate conditions and mulching. Folia Horticulture. pp: 19-24.

Stapleton, J. J. and Summers, C.G. 1995. Spectral and temperature modifying properties of reflectorized spray mulch and its role in management of aphidtransmitted virus diseases of melons. (Abstr.). Phytopathol. 85: 1196.

Stapleton, J.J., Mahmoudpour A. and Summers, C.G. 1995. Influence of spray mulch color on yield of Eggplant in the san joaquin valley. Pp. 1-3.

Sumeet Singh, Kulbir Singh, D.S. Khurana and Sardana, V. 2017. Economic Analysis of Integrated Weed Management in Brinjal Crop (Solanum melongena L.) Int.J.Curr.Microbiol. App.Sci. 6(12): 1245-1251.

\section{How to cite this article:}

Shweta, D. Mal, L. Singh, S. Gharde, P. Kaur and Datta, S. 2018. Effect of Mulching in Brinjal (Solanum melongena L.): A Review. Int.J.Curr.Microbiol.App.Sci. 7(06): 504-509. doi: https://doi.org/10.20546/ijcmas.2018.706.056 